\title{
Evaluation of Catalytic Efficiency of Coriolopsis caperata DN Laccase to Decolorize and Detoxify RBBR Dye
}

\author{
Ajit M. Patel ${ }^{1}$ • Vanita M. Patel ${ }^{2} \cdot$ Juhi Pandya $^{3} \cdot$ Ujjval B. Trivedi $^{3} \cdot{\text { Kamlesh C. } \text { Patel }^{3}}^{3}$
}

Received: 9 March 2017 /Revised: 31 July 2017 / Accepted: 1 August 2017 /Published online: 13 August 2017

(C) Springer Nature Singapore Pte Ltd. 2017

\begin{abstract}
Application of enzymes for the removal of environmentally hazardous synthetic dyes from waste water has been considered eco-friendly and economic as compared with nonenzymatic techniques. In the present study, response surface methodology has been applied to decolorize and detoxify a recalcitrant and toxic anthraquinone dye Remazol Brilliant Blue R (RBBR) using Coriolopsis caperata DN laccase. Optimum concentrations of laccase, $\mathrm{pH}$, and temperature for decolorization of RBBR dye (100 to $500 \mathrm{ppm}$ ) were $0.5 \mathrm{U} \mathrm{ml}^{-1}, 3.5$, and $40{ }^{\circ} \mathrm{C}$, respectively. Result of RSM showed that optimum value of tested variables for maximum dye decolorization was $1 \mathrm{U} \mathrm{ml}^{-1}$ enzyme, $1000 \mathrm{ppm}$ dye, and $60 \mathrm{~min}$. Result of kinetic study showed that the $K_{\mathrm{m}}, V_{\mathrm{max}}, K_{\text {cat }}$, and $K_{\text {cat }} / K_{\mathrm{m}}$ values for RBBR decolorization were $1.06 \mathrm{mM}$, $0.226 \mathrm{mM} \mathrm{U}^{-1} \mathrm{~min}^{-1}, 135 \mathrm{~S}^{-1}$ and $1.27 \times 10^{5} \mathrm{~S}^{-1} \mathrm{M}^{-1}$, respectively. The thermodynamic studies (Ea, $10.87 \mathrm{~kJ} \mathrm{M}^{-1}$; $\Delta H, 7.408 \mathrm{~kJ} \mathrm{M}^{-1}$; and $\Delta S, 80.06 \mathrm{~J} \mathrm{M}^{-1} \mathrm{~K}$ ) follow firstorder kinetics, and the reaction is endothermic with a negative value of $\Delta G$, suggesting spontaneous nature of reaction. The results of HPTLC, FTIR, and LC-MS analysis confirmed oxidative cleavage of $\mathrm{N}-\mathrm{H}$ bond of RBBR dye by laccase. Treatment of laccase significantly reduced toxicity (phyto-, cyto-, and micro-) of RBBR dye. The present investigation confirmed $C$. caperata DN laccase as an efficient biocatalyst for bioremediation of textile dyes.
\end{abstract}

Kamlesh C. Patel

comless@yahoo.com

J. \& J. College of Science, Nadiad, Gujarat 388120, India

2 V. P \& R.P.T.P Science College, Vallabh Vidyanagar, Gujarat 388120, India

3 P. G. Department of Biosciences, Sardar Patel University, Vallabh Vidyanagar, Gujarat 388120, India
Keywords Bioremediation $\cdot$ Kinetics $\cdot$ Pollution $\cdot$ Response surface methods $\cdot$ Toxicity $\cdot$ Wastewater

\section{Introduction}

One of the major and serious problems of the modern world is environmental pollution. Highly colored waste water generated by industries like textile, paper and pulp, dyestuff, distillery, tanneries, printing, cosmetic, plastic, and pharmaceuticals is a major contributor to pollution problem. Many different types of synthetic dyes having complex organic structures including acidic, basic, disperse, azo, diazo, anthraquinone based, and metal complex are used by these industries. Every year, at least $10 \%$ of the used dyestuff enters in the environment out of 800,000 tons of world production [1]. Anthraquinone dye Remazol Brilliant Blue R (RBBR) is frequently used for the production of polymeric dyes but has toxicity and recalcitrance due to the anthracene derivative [2] and is possibly carcinogenic to humans (group 2B) (https:// monographs.iarc.fr/ENG/Monographs/vol101/mono101-001). Presence of dyes in water can cause diseases like hemorrhage, ulceration of skin, nausea, severe irritation of skin, and dermatitis. It also hampers the growth of photoautotrophic organisms and increases the biochemical oxygen demand of the water [3]. Due to complex chemical structure and synthetic origin, dyes are usually resistant to decolorization by exposure to light, water, and various chemicals [4]. The strong persistent color, high biological oxygen demand (BOD), and carcinogenicity are environmentally unacceptable [5] which direct to develop efficient and economical processes for the degradation of synthetic dyes.

Enzymatic removal of synthetic dyes is more acceptable as compared with conventional physicochemical techniques because of its simplicity, low cost, effectivity over a wide range 
of pollutant concentration and physiological condition, minimal impact on ecosystem and less sludge production. The pathway used by different microorganisms/enzymes for the degradation of dyes depends on dye structure. It is necessary to identify the products after biodegradation to determine the mechanistic pathways involved and assess the toxicity of the intermediates or degraded product compared with original dyes [6].

Laccases can decolorize broad range of synthetic dyes by catalyzing mono-electronic oxidation of molecules to corresponding reactive radicals with conversion of oxygen to water [7]. Hence, laccase and laccase-mediated system (LMS)assisted dye decolorization may provide a reasonable basis for the development of biotechnological processes for removal of color and aromatic compounds from various industrial effluents at large scale [8-10]. For development of sustainable technology, it is necessary to isolate new microorganisms and enzymes, with broader substrate specificity and higher activity to control pollution [6]. For making the overall process cost effective and time saving, statistical approaches like response surface methodology (RSM) can be applied to optimize enzymatic dye decolorization process. Recently, the potential application of RSM in the laccase-mediated decolorization of various dyes has been published [11].

The present research work has been undertaken to evaluate the potential of laccase from Coriolopsis caperata DN to decolorize RBBR dye using statistical design (response surface methodology) where RBBR dye concentration, laccase concentration, and time were considered important parameters. Kinetic and energetic study of RBBR decolorization by laccase, analysis of biotransformation products using highperformance thin-layer chromatography (HPTLC), Fourier transforms infrared spectroscopy (FTIR), and liquid chromatography-mass spectroscopy (LC-MS), as well as the assessment of the toxicity of degraded RBBR dye products have also been carried out.

\section{Materials and Methods}

\section{Chemicals}

RBBR and 2,2'-azino-bis-(3-ethylbenzthiazoline-6sulphonate) (ABTS) were from Sigma-Aldrich (St. Louis, MO, USA). The chemical formula of RBBR dye is $\mathrm{C}_{22} \mathrm{H}_{16} \mathrm{~N}_{2} \mathrm{Na}_{2} \mathrm{O}_{11} \mathrm{~S}_{3}$, and its molecular weight is $626.54 \mathrm{~g} \mathrm{M}^{-1}$.

\section{Production and Partial Purification of Laccase}

White rot fungus isolated from natural source was identified as $C$. caperata DN (NCBI, accession no. KF564288). Laccase enzyme was produced by $C$. caperata $\mathrm{DN}$ in statistically optimized medium under submerged condition. The fermented broth obtained after separation of mycelial mass from the medium was subjected to fractional precipitation by ammonium sulfate. The enzyme protein precipitated between 40 and $60 \mathrm{~g} \%(w / v)$ was collected and then suspended in $100 \mathrm{mM}$ sodium phosphate buffer $(\mathrm{pH} 7.0)$ and dialyzed against the same buffer overnight at $4{ }^{\circ} \mathrm{C}$ with three changes of equal intervals. The dialyzed enzyme solution was used for the decolorization of RBBR dye.

\section{Laccase Enzyme Assay}

Extracellular laccase activity (E.C.1.10.3.2) was measured at $30{ }^{\circ} \mathrm{C}$ by the oxidation of ABTS. The reaction mixture contained $500 \mu \mathrm{l}$ of $1.0 \mathrm{mM}$ ABTS, $2400 \mu \mathrm{l}$ of $20 \mathrm{mM} \mathrm{Na}$ acetate butter ( $\mathrm{pH} 3.5$ ), and $100 \mu \mathrm{l}$ of appropriately diluted enzyme sample. Increase in absorbance for 5 min was measured spectrophotometrically using SPECORD 200 PLUS Spectrophotometer against a suitable blank at $436 \mathrm{~nm}$ $\left(\varepsilon=29,300 \mathrm{~cm}^{-1} \mathrm{M}^{-1}\right)$ [12]. One enzyme unit $(\mathrm{U})$ was defined as $1.0 \mu \mathrm{M}$ of product $\left(\mathrm{ABTS}^{+}\right)$formed per minute under the assay conditions.

\section{Optimization of RBBR Dye Decolorization}

\section{Effect of Physicochemical Parameter on Dye Decolorization}

Stock solution of RBBR dye (1000 ppm) was prepared in $100 \mathrm{ml}$ deionized water. The decrease in the spectral absorbance during decolorization of RBBR dye $(592 \mathrm{~nm})$ by laccase was recorded using UV-visible spectrophotometer. Effect of $\mathrm{pH}$ was studied at different $\mathrm{pH}$ ranges $(\mathrm{pH} 2.5-$ 7.0). Influence of temperature towards decolorization of dyes was studied at optimum $\mathrm{pH}$ at different temperature ranges $\left(10-50{ }^{\circ} \mathrm{C}\right)$. Effect of temperature on the rate of dye decolorization was expressed in terms of temperature quotient $\left(Q_{10}\right)$ value which is a measure of the temperature sensitivity of an enzymatic reaction rate by $10{ }^{\circ} \mathrm{C}[13]$.

$Q_{10}=\operatorname{antilog} \mathrm{e}\left(E_{\mathrm{ax}} 10 / \mathrm{RT}^{2}\right)$

A control test containing the same amount of a heatdenatured laccase was performed in parallel. The percentage of dye decolorization was calculated according to Xin and Geng [14] by using the formula:

$D=100 \times\left(A_{\text {ini }}-A_{\text {obs }} / A_{\text {ini }}\right)$

where $D$ is the percent decolorization, $A_{\text {ini }}$ is the initial absorbance, and $A_{\mathrm{obs}}$ is the observed absorbance. Decolorization percentage of RBBR dye was converted to milligrams per millilter and finally in millimolar concentration. 


\section{Statistical Optimization of RBBR Dye Decolorization}

Central composite design of RSM was performed to optimize the concentration of RBBR dye, laccase enzyme, and time in minutes. The range of coded and uncoded variables is given in Table 1. A five-level three-factor CCD requiring 20 experiments was used in the study (Table 2). The CCD consist of a $2^{\mathrm{K}}$ factorial runs with $2 \mathrm{k}$ axial runs and $X_{0}$ number of center points (six replicates). The number of experimental run was calculated as:

$N=2^{k}+2 K+X_{0}$

where $N$ is total experimental run (20), $K$ is number of variables (3), and $X_{0}$ is the number of central points (6). The behavior of the system was explained by the following quadratic equation.

$Y=\beta_{0}+\sum \beta_{i} X_{i}+\sum \beta_{i j} X_{i} X_{j}+\sum \beta_{i i} X_{i}^{2}$

where $Y$ is predicted response, $\beta_{0}$ is constant, $\beta_{i}$ is linear term coefficient, $\beta_{i i}$ is quadratic term coefficient, $\beta_{i j}$ is interaction coefficient, and $X_{i}$ is dimensionless-coded value of $X_{i}$ [15]. Quadratic multiple regression equation and the response surface contour plots (Design Expert software (version 9) from Stat-Ease, Inc., Minneapolis, MN, USA) were used to analyze and interpret the data of RBBR degradation. After optimization, an experiment was run using the optimum values for variables to validate the predicted and experimental value of RBBR degradation.

\section{Kinetics and Thermodynamics of RBBR Decolorization}

\section{Kinetics of Decolorization}

To optimize the concentration of laccase for decolorization of RBBR dye, 0.2 to $2.0 \mathrm{U} \mathrm{ml}^{-1}$ of enzyme and $100 \mathrm{ppm}$ RBBR dye was used under optimized condition. Optimized enzyme concentration was used for decolorization of the dye $(0.079-0.79 \mathrm{mM})$ at different time intervals, and the velocity was determined by using the slope at each

Table 1 Experimental range and levels of the independent variables of selected components used for response surface central composite design

\begin{tabular}{llllll}
\hline & $-\alpha$ & -1 & 0 & +1 & $+\alpha$ \\
\hline Laccase $\left(\mathrm{U} \mathrm{ml}^{-1}\right)$ & -0.41 & 0.2 & 1.1 & 2.0 & 2.61 \\
RBBR dye $\left(\mathrm{mg} \mathrm{l}^{-1}\right)$ & -273.85 & 50.0 & 525.0 & 1000 & 1323.85 \\
Time (min) & -13.74 & 5.0 & 32.5 & 60.0 & 78.74 \\
\hline
\end{tabular}

Table 2 Central composite design with actual and coded level of variables and their response

\begin{tabular}{|c|c|c|c|c|c|c|}
\hline Std & Run & $\begin{array}{l}\text { Factor } 1 \\
\text { A-A } \\
\text { laccase } \\
\left(\mathrm{U} \mathrm{ml}^{-1}\right)\end{array}$ & $\begin{array}{l}\text { Factor } 2 \\
\text { B-B } \\
\text { RBBR } \\
\text { dye } \\
\left(\mathrm{mg} \mathrm{l}^{-1}\right)\end{array}$ & $\begin{array}{l}\text { Factor } 3 \\
\text { C-C } \\
\text { time } \\
(\mathrm{min})\end{array}$ & $\begin{array}{l}\text { Response } \\
\left(\mathrm{mg} \mathrm{l}^{-1}\right)\end{array}$ & $\begin{array}{l}\text { Predicted } \\
\text { value } \\
\left(\mathrm{mg} \mathrm{l}^{-1}\right)\end{array}$ \\
\hline 11 & 1 & 1.1 & 00.0 & 32.5 & 0.000 & 3.57 \\
\hline 8 & 2 & 2.0 & 1000 & 60.0 & 674.58 & 679.99 \\
\hline 1 & 3 & 0.2 & 50.0 & 5.0 & 3.701 & -0.82 \\
\hline 2 & 4 & 2.0 & 50. & 5.0 & 32.46 & 30.87 \\
\hline 13 & 5 & 1.1 & 525.0 & 00.0 & 0.000 & 3.51 \\
\hline 18 & 6 & 1.1 & 525.0 & 32.5 & 261.42 & 261.50 \\
\hline 12 & 7 & 1.1 & 1323.85 & 32.5 & 557.25 & 552.44 \\
\hline 16 & 8 & 1.1 & 525.0 & 32.5 & 259.28 & 261.50 \\
\hline 7 & 9 & 0.2 & 1000.0 & 60.0 & 335.76 & 338.24 \\
\hline 15 & 10 & 1.1 & 525.0 & 32.5 & 267.85 & 261.50 \\
\hline 20 & 11 & 1.1 & 525.0 & 32.5 & 258.21 & 261.50 \\
\hline 19 & 12 & 1.1 & 525.0 & 32.5 & 262.39 & 261.50 \\
\hline 9 & 13 & 00.0 & 525.0 & 32.5 & 0.000 & 2.75 \\
\hline 5 & 14 & 0.2 & 50.0 & 60.0 & 31.562 & 30.60 \\
\hline 4 & 15 & 2.0 & 1000.0 & 5.0 & 374.11 & 375.96 \\
\hline 10 & 16 & 2.61 & 525.0 & 32.5 & 320.76 & 316.77 \\
\hline 3 & 17 & 0.2 & 1000.0 & 5.0 & 19.52 & 18.62 \\
\hline 6 & 18 & 2.0 & 50.0 & 60.0 & 44.90 & 46.69 \\
\hline 14 & 19 & 1.1 & 525.0 & 78.74 & 290.34 & 285.59 \\
\hline 17 & 20 & 1.1 & 525.0 & 32.5 & 259.60 & 261.50 \\
\hline
\end{tabular}

dye concentration (Fig. 1c). The Michaelis-Menten curve was then drawn by plotting the obtained initial velocity $\left(1 / V_{0}\right)$ against dye concentrations $(1 / S)$. The kinetic constants $\left(V_{\mathrm{max}}, K_{\mathrm{m}}, K_{\text {cat }}\right.$, and $\left.K_{\text {cat }} / K_{\mathrm{m}}\right)$ were determined by Michaelis-Menten kinetics.

\section{Thermodynamics of RBBR Degradation}

The effect of temperature on decolorization of RBBR was evaluated by performing the dye decolorization $(0.1-$ $0.5 \mathrm{mM}$ ) experiment at $10-50{ }^{\circ} \mathrm{C}$ temperature, and the obtained velocities (for each temperature) were plotted against initial dye concentrations. The apparent first-order rate constant $(K)$ for each temperature was calculated based on the slope of each trend line. The Arrhenius curve achieved by drawing the $\ln$ $(K)$ versus $1 / T\left(\times 10^{3} \mathrm{~K}^{-1}\right)(T$ is the absolute temperature $(K))$ was used to calculate the value of activation energy (Ea). The slope of Arrhenius plot indicates $-\mathrm{Ea} / R$ where $\mathrm{Ea}$ is activation energy and $R$ is the gas constant $(8.3145 \mathrm{~J} / \mathrm{mol} K)$. $K_{\text {eq }}$ is the apparent equilibrium constant and was calculated from the difference of initial dye concentration and residual dye concentration at equilibrium state [16]. The Van't 
Fig. 1 Kinetics study of RBBR dye decolorization. a

Optimization of concentration of laccase. b The time course study of RBBR ( 0.0798 to $0.798 \mathrm{mM}$ ) decolorization by laccase. $\mathbf{c}$ Straight line graph was obtained from (b) to find out $V_{0}$ (slope of trend line) for each dye concentration. $\mathbf{d}$ The LineweaverBurk plot was drawn using $V_{0}$ values obtained from (c) $V_{\mathrm{s}} 1 / S$
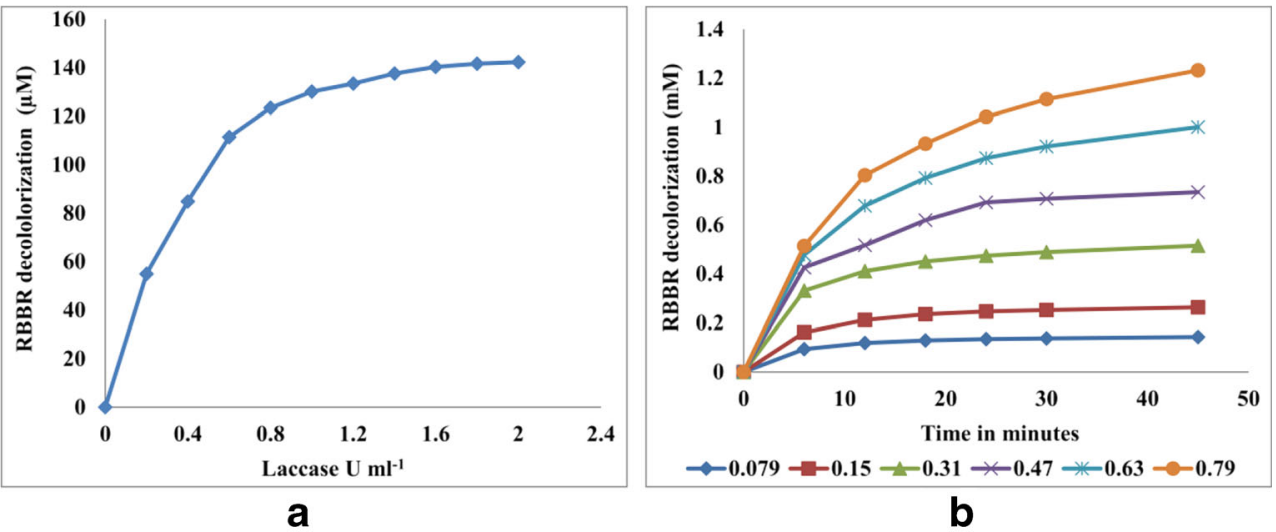

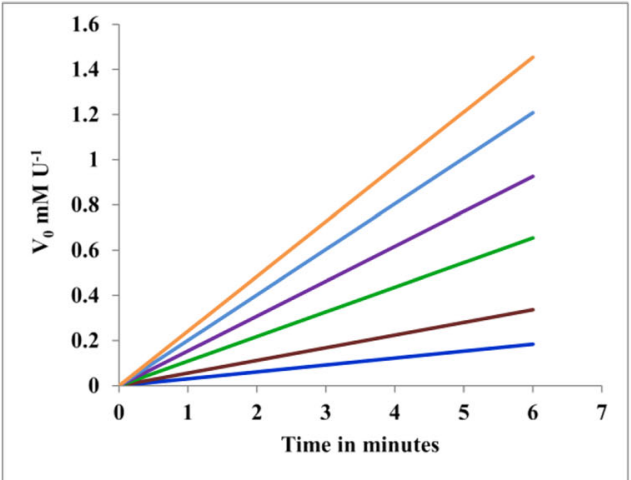

C

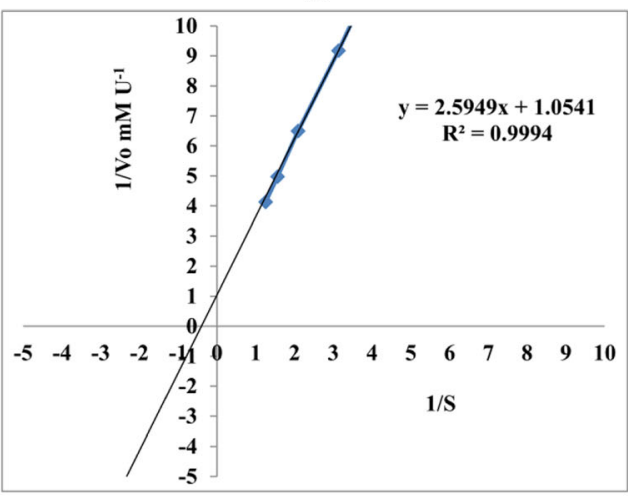

d
Hoff plot was drawn by plotting the $\ln \left(K_{\text {eq }}\right)$ against $1 / T$ $\left(\times 10^{3} \mathrm{~K}^{-1}\right)$ and used to estimate the enthalpy $(\Delta H)$ and entropy $(\Delta S)$ while the Gibbs free energy $(\Delta G)$ was calculated using the equation:

$\Delta G=\Delta H-T \Delta S$.

\section{Analysis of Metabolites of RBBR Degradation}

\section{Spectral Scanning}

After decolorization of RBBR dye (100-500 ppm) by laccase, the spectral scan (190-1100 nm) of each solution was carried out using UV spectrophotometer and changes in its absorption spectrum were recorded.

\section{High-Performance Thin-Layer Chromatography}

HPTLC chromatogram was obtained by spotting metabolites obtained after decolorization on the silica gel-coated glass plate. The composition of mobile phase was water:butanol:glacial acetic acid:pyridine $(2: 4: 1: 1, v / v)$. The control dye and postdegradation metabolites were analyzed by scanning at $200-800 \mathrm{~nm}$ using TLC scanner
(CAMAG), and the results were generated by using HPTLC software WinCATS 1.4.4.6337.

Fourier Transforms Infrared Spectroscopy

FTIR analysis was done in the mid-IR region of 400 $4000 \mathrm{~cm}^{-1}$ with 16 scan speed. The pellets prepared using spectroscopic pure $\mathrm{KBr}$ (5:95) were fixed in a sample holder to carry out analysis.

\section{Liquid Chromatography-Mass Spectroscopy}

Identification of postdegradation metabolites of RBBR was carried out using a LC 8030 gas chromatography coupled with mass spectroscopy (Shimadzu, Japan). The ionization voltage was $35 \mathrm{eV}$, and nitrogen was used as a carrier gas with a flow rate $0.5 \mathrm{ml} \mathrm{min} \mathrm{m}^{-1}$ and $35 \mathrm{~min}$ run time. Gas chromatography was conducted in temperature programming mode with a $\mathrm{C}-18$ column $(4.6 \times 150 \mathrm{~m}$; particle size is $5 \mu \mathrm{m}$ ). The mobile phase was composed of acetonitrile and distilled water $(65: 35)$ while the temperature of column oven was $280{ }^{\circ} \mathrm{C}$ and of injection was $200{ }^{\circ} \mathrm{C}$. Temperature was hold at $40{ }^{\circ} \mathrm{C}$ for $1 \mathrm{~min}$ then rose to $280{ }^{\circ} \mathrm{C}$ at $10^{\circ} \mathrm{C}$ rise $\min ^{-1}$ [2]. 


\section{Toxicity Test}

\section{Phytotoxicity Assay}

Phytotoxicity test was carried out in order to assess the toxicity of RBBR before and after laccase treatment using Phaseolus mungo (dicot), pulses normally cultivated in India. Phytotoxicity was conducted at room temperature using different concentrations of control dye $(100,50,25$, and $12.5 \mathrm{ppm})$ and laccase-treated dye. Twenty seeds of P. mungo were soaked in $10 \mathrm{ml}$ solution of control RBBR and its degradation products for $24 \mathrm{~h}$ while distilled water was used as control. After 24-h incubation, the seeds were placed in a glass petriplates, containing a filter paper soaked in $2 \mathrm{ml}$ of each dye concentration. The plates were incubated in the dark for 3 days. Germination percentage of seeds as well as the length of radical was recorded after incubation, and the germination index (GI) was calculated by Eq. (5) while the inhibitory concentration that causes $50 \%$ inhibition of growth of radicals $\left(\mathrm{IC}_{50}\right)$ was also calculated.

$\mathrm{GI}=\left(\mathrm{GP} \times I_{a}\right) / I_{c}$

where GP is germinated seeds expressed as percentage of control value and $I_{\mathrm{a}}$ and $I_{\mathrm{c}}$ were average root length $(\mathrm{mm})$ in dye solution and in the control, respectively.

\section{Acute Toxicity Assay}

For acute toxicity test, the freshwater copepod Cyclops was used according to the methodology developed by Marus et al. [17]. The adult Cyclops was transferred to each set of tubes (ten per tube) with different concentrations of control dye (100, 50, 25 , and $12.5 \mathrm{ppm}$ ) and enzyme-treated dye. Negative control (aerated distilled water) was kept in parallel. The number of surviving Cyclops was counted after $24 \mathrm{~h}$ of incubation, and the lethal concentration $\left(\mathrm{LC}_{50}\right)$ was calculated.

\section{Microtoxicity Assay}

To determine the microtoxicity of RBBR dye before and after laccase treatment, two Gram-negative (Escherichia coli, Enterobacter aerogenes) and three Gram-positive (Micrococcus luteus, Staphylococcus aureus, and Bacillus subtilis) bacterial cultures were used. A culture of each bacterial strain was prepared in Muller-Hinton broth, and 0.2 optical densities were set at $\mathrm{OD}_{600}$. Filter-sterilized RBBR dye solution (laccase-treated and untreated) with100 ppm concentration was separately added to each culture medium and incubated at $37^{\circ} \mathrm{C}$ for $10 \mathrm{~h}$. Change in $\mathrm{OD}_{600}$ was recorded after every $2 \mathrm{~h}$ for each bacterial strain, and the results were analyzed as percentage of growth inhibition (GI\%) which was calculated as
$\mathrm{GI} \%=\left[\left(1-\mathrm{OD}_{600 \mathrm{~s}} / \mathrm{OD}_{600 \mathrm{c}}\right) \times 100\right]$

where $\mathrm{OD}_{600 \mathrm{~s}}$ is the $\mathrm{OD}_{600}$ of sample and $\mathrm{OD}_{600 \mathrm{c}}$ is the $\mathrm{OD}_{600}$ of control.

\section{Result and Discussion}

Ligninolytic white rot fungi effectively degrade recalcitrant synthetic dyes due to the production of extracellular ligninolytic enzymes, mainly laccases [11, 18-20]. In the present study, we used laccase enzyme produced by indigenous fungal isolate $C$. caperata $\mathrm{DN}$, under submerged condition, to decolorize and detoxify anthraquinone dye RBBR.

\section{Physiological Optimization of RBBR Decolorization}

The effect of $\mathrm{pH}$ and temperature were studied at $\mathrm{pH}$ values between 2.5 and 7.0 and temperature between 10 and $50{ }^{\circ} \mathrm{C}$ using $100 \mathrm{ppm}$ dye and $0.5 \mathrm{U} \mathrm{ml}^{-1}$ laccase. Optimum $\mathrm{pH}$ for decolorization of RBBR was 3.5, and the range of $\mathrm{pH}$ was 3.0 to 6.0 while the optimal temperature for decolorization was $40^{\circ} \mathrm{C}$. Fungal laccases decolorize all applied dyes maximally at acidic $\mathrm{pH} 5.0$ [21]. The enzyme activity is decreased at higher $\mathrm{pH}$ due to the binding of $\mathrm{OH}^{-}$ion to T2/T3 coppers of laccase which interrupt the internal electron transfer from $\mathrm{T} 1$ to T2/T3 centers of laccase [22]. The rate of reaction of dye decolorization was enhanced by increasing temperature, and the optimum temperature for dye decolorization was $40-60{ }^{\circ} \mathrm{C}$ [23] which was in agreement with the obtained result. Temperature quotient $\left(Q_{10}\right)$ value which gives an increase of rate of reaction due to rise in temperature by $10{ }^{\circ} \mathrm{C}$ was 1.49 . The effect of laccase concentration on the rate of RBBR decolorization was studied by using laccase concentration from 0.2 to $2.0 \mathrm{U} \mathrm{ml}^{-1}$ with dye concentration at $100 \mathrm{mg} \mathrm{l}^{-1}$. The rate of RBBR decolorization linearly increased up to $0.5 \mathrm{U} \mathrm{ml}^{-1}$ of enzyme (Fig. 1a); hence, $0.5 \mathrm{U} \mathrm{ml}^{-1}$ concentration of laccase was selected for further study. The result of RBBR ( 0.079 to $0.79 \mathrm{mM}$ ) decolorization after treatment with the laccase at different time intervals is shown in Fig. 1b, which shows that the RBBR decolorization rate is linear with increasing concentration of dye up to $6.0 \mathrm{~min}$ and all the concentration of RBBR was decolorized up to $75.0 \%$ within 45.0 min under optimized condition. The spectral scan $(190-1100 \mathrm{~nm})$ result of RBBR dye (100 ppm) before and after laccase treatment to various concentrations of RBBR dye (100-500 ppm) indicates (Fig. 2 (b)) that the peak of parent dye RBBR disappears and a new peak is obtained, suggesting oxidation of dye. 


\section{Optimization of RBBR Decolorization Using RSM}

Substrate concentration affects the velocity of reaction, while enzyme concentration affects the cost of bioprocess. The responses generated by performing a total of 20 runs which include concentration of each component at two levels were used to obtain quadratic model presented in Table 2 . The value of lack of fit, model $F$ value, and model $p$ value were found to be $2.66,3589.38$, and $<0.0001$, respectively, indicating that the model was significant. In addition, Table 3 indicates laccase activity (A), dye concentration (B), time (C), and their interactions; $\mathrm{AB}, \mathrm{BC}, \mathrm{A}^{2}$, and $\mathrm{C}^{2}$ as significant model terms ( $p$ value $<0.0001)$. The coefficient of determination $R^{2}$ is also applied to analyze the fitness of model, and in the present study, it was found to be 0.998 indicating that only less than $0.20 \%$ of the total variance could not be explained by the model. The "pred r-squared" of 0.99 is in reasonable agreement with the "Adj r-squared" of 0.99. "Adeq Precision" measures the signal-to-noise ratio, and it is 204.61 which is greater than 4.0 and indicates adequate signals. The higher significance of squared terms $\left(\mathrm{A}^{2}, \mathrm{C}^{2}\right)$ shown in Table 3 indicates that optimum values of variables used for dye decolorization are within the range of selected values [15]. The low coefficient variation $(2.21 \%)$ confirms the precision and reliability of the model experiment performed. The quadratic model explains the statistical relationship between the selected variables, and the response in terms of coded factors was best fitted with the following equation.

Dye decolorization $(\mathrm{R} 1)=(-37.96)-(106.56 \times \mathrm{A})+(-0.07 \times \mathrm{B})+(3.88 \times \mathrm{C})-$

$$
\begin{aligned}
& (0.19 \times \mathrm{A} \times \mathrm{B})-(-0.15 \times \mathrm{A} \times \mathrm{C})+(5.51 \times \mathrm{B} \times \mathrm{C})+ \\
& \left(-44.40 \times \mathrm{A}^{2}\right)+\left(2.58 \times \mathrm{B}^{2}\right)+\left(-0.05 \times \mathrm{C}^{2}\right)
\end{aligned}
$$

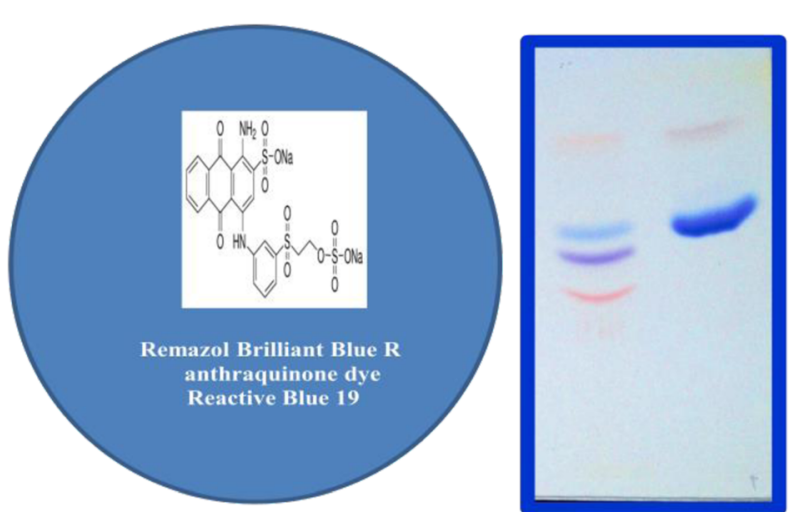

a

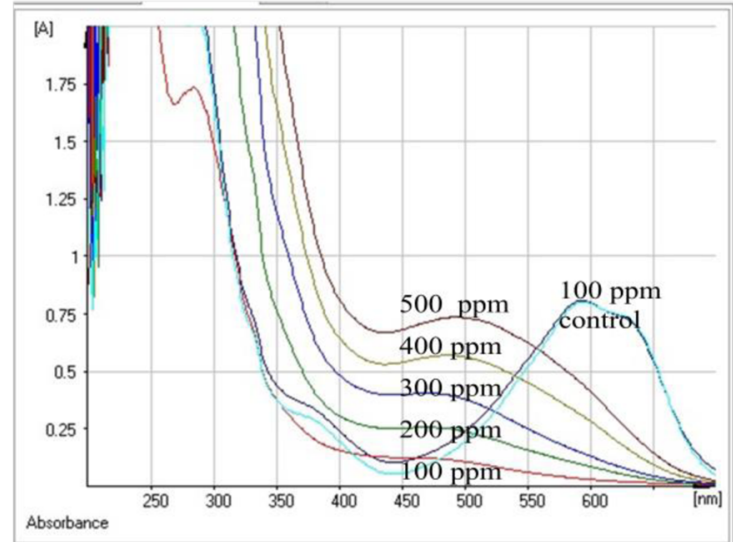

b

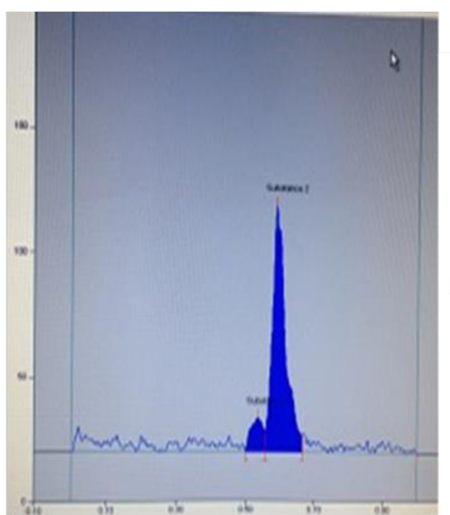

c1

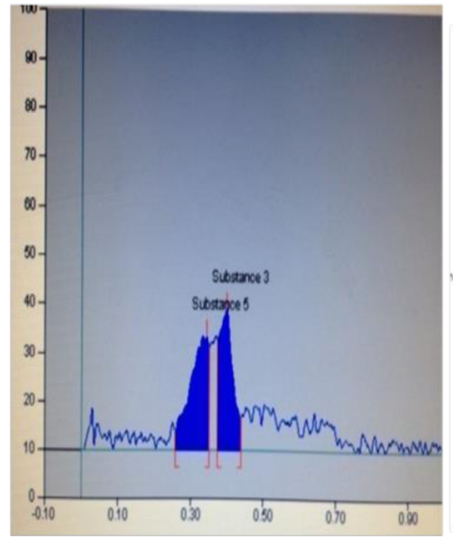

c2

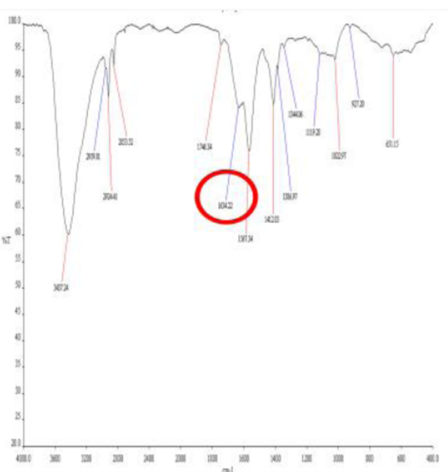

d1

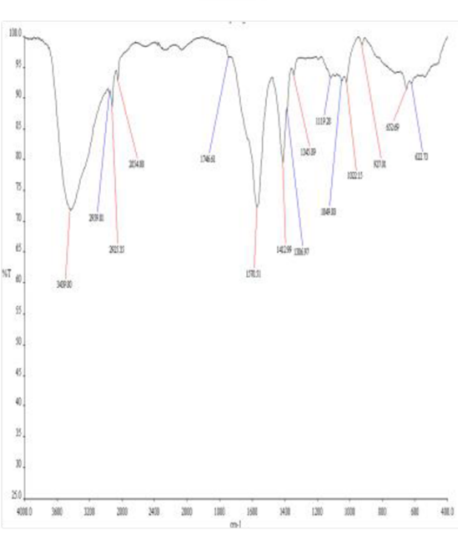

d2

Fig. 2 Analysis of RBBR degradation products by TLC (a). Spectral scan result of RBBR dye before and after laccase treatment (b). HPTLC analysis of RBBR dye $(c 1)$ and its product $(c 2)$. FTIR analysis of control dye $(d 1)$ and degraded product $(d 2)$ 
Table 3 Analysis of variance of quadratic model for decolorization of RBBR dye

\begin{tabular}{lllllll}
\hline Source & Sum of squares & $d f$ & Mean squares & $F$ value & $p$ value & \\
\hline Model & $7.15 \mathrm{E}+005$ & 9 & $79,471.08$ & 3589.38 & $<0.0001$ & Significant \\
A-A laccase & $1.19 \mathrm{E}+005$ & 1 & $1.190 \mathrm{E}+005$ & 5376.06 & $<0.0001$ & Significant \\
B-B RBBR dye & $3.63 \mathrm{E}+005$ & 1 & $3.637 \mathrm{E}+005$ & $16,424.89$ & $<0.0001$ & Significant \\
C-C time & $96,048.53$ & 1 & $96,048.53$ & 4338.11 & $<0.0001$ & Significant \\
AB & $53,024.77$ & 1 & $53,024.77$ & 2394.91 & $<0.0001$ & \\
AC & 121.60 & 1 & 121.60 & 5.49 & 0.0411 & \\
BC & $41,531.13$ & 1 & $41,531.13$ & 1875.79 & $<0.0001$ & \\
A $^{2}$ & $18,645.84$ & 1 & $18,645.84$ & 842.15 & $<0.0001$ & \\
$B^{2}$ & 490.70 & 1 & 490.70 & 22.16 & 0.0008 & \\
$C^{2}$ & $24,637.28$ & 1 & $24,637.28$ & 1112.76 & $<0.0001$ & \\
Residual & 221.41 & 10 & 22.14 & & & Not significant \\
Lack of fit & 160.92 & 5 & 32.18 & 2.66 & 0.1533 & \\
\hline
\end{tabular}

Coefficient of variance, 2.21; predicted $R$-squared, 0.99; adjusted $R$-squared, 0.99; and adequate precision, 204.61 $d f$ degree of freedom, $p$ probability where R1 is the response (yield of decolorization) and A, B, and $\mathrm{C}$ are laccase activity, dye concentration, and time, respectively.

In order to investigate the relation between independent variables and their responses, contour plots were generated by RSM using the Design Expert software. The response surface plots (Fig. 3) presents the decolorization of RBBR dye as function of two variables while the third one is kept at a constant level. Surface plot demonstrates an increase in dye decolorization with rise in the enzyme concentration. Figure 3a, c clearly shows that even small alterations of the enzyme concentration influence the decolorization rate. On the basis of the result of R1 and three-dimensional response surface graphs (Fig. 3), the optimal levels for enzyme activity, dye concentration, and time were found to be $1 \mathrm{U} \mathrm{ml}^{-1}$, $1000 \mathrm{mg} \mathrm{l}^{-1}$, and $60 \mathrm{~min}$, respectively. Validation was carried out by solving Eq. (7) and analyzing response surface graphs. As shown in Table 4, the maximum decolorization efficiency is $542.77 \pm 9.21 \mathrm{mg} \mathrm{l}^{-1}$ implying a strong similarity between experimental and predicted values. Osma et al. [24] reported

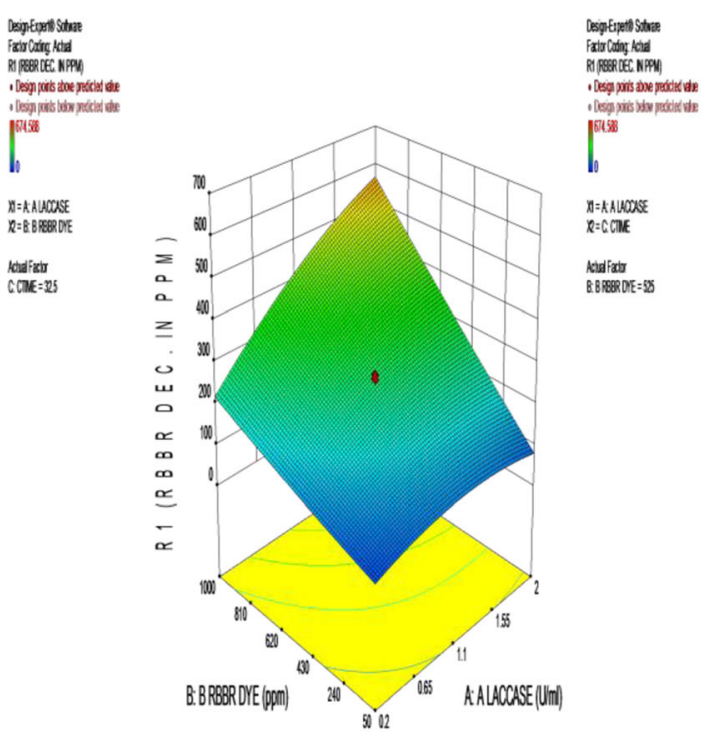

a

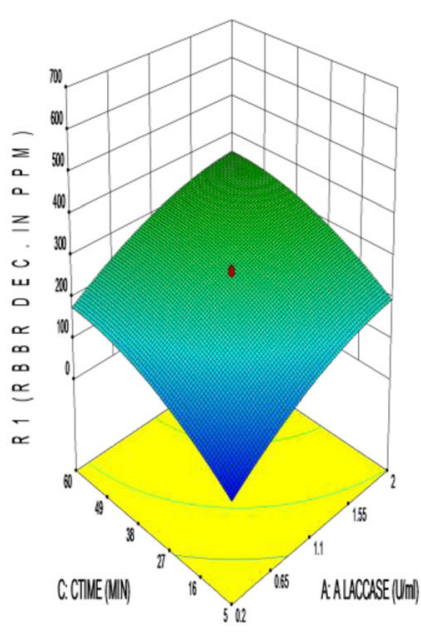

b
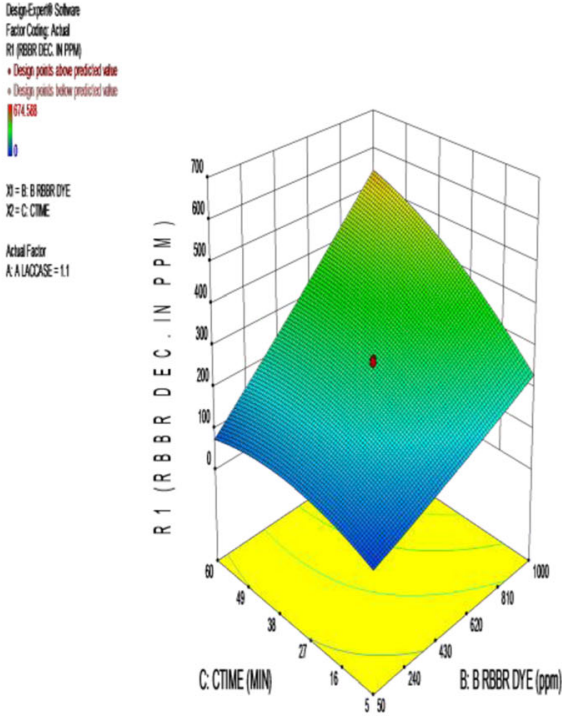

C

Fig. 3 Contour plots showing the interaction effect between a laccase and RBBR dye concentration, $\mathbf{b}$ laccase and time in minutes, and $\mathbf{c}$ RBBR dye concentration and time in minutes 
Table 4 Validation of RSM results using statistically optimal condition

\begin{tabular}{llllll}
\hline No. & $\begin{array}{l}\text { Laccase } \\
\left(\mathrm{U} \mathrm{ml}^{-1}\right)\end{array}$ & $\begin{array}{l}\text { RBBR dye } \\
\left(\mathrm{mg} \mathrm{l}^{-1}\right)\end{array}$ & Time (min) & $\begin{array}{l}\text { Experimental } \\
\text { result }^{\mathrm{a}}\left(\mathrm{mg} \mathrm{l}^{-1}\right)\end{array}$ & $\begin{array}{l}\text { Predicted result } \\
\left(\mathrm{mg} \mathrm{l}^{-1}\right)\end{array}$ \\
\hline 1 & 1 & 1000.00 & 60.0 & $542.77 \pm 9.21$ & 525.65 \\
2 & 1 & 270.79 & 18.0 & $115.86 \pm 5.52$ & 122.842 \\
\hline
\end{tabular}

${ }^{\mathrm{a}}$ Mean \pm standard deviation that $5 \mathrm{U} \mathrm{ml}^{-1}$ immobilized laccase of Trametes pubescens decolorize $44 \%$ of RBBR (133.0 $\mathrm{mg} \mathrm{l}^{-1}$ ) within $42 \mathrm{~h}$. Kunamneni et al. [25] observed that $20 \mathrm{U} \mathrm{ml}^{-1}$ of immobilized Myceliophthora thermophila laccase in the presence of $1 \mathrm{mM}$ HBT decolorize $31 \%$ of RBBR (200.0 $\mathrm{mg} \mathrm{l}^{-1}$ ) within $24 \mathrm{~h}$. Murugesan et al. [26] used $25 \mathrm{U} \mathrm{ml}^{-1}$ of Ganoderma lucidum laccase in the presence of HBT to obtain $92 \%$ of RBBR (50 $\mathrm{mg} \mathrm{l}^{-1}$ ) decolorization within $2 \mathrm{~h}$. Laccase from Trametes trogii at $0.2 \mathrm{U} \mathrm{ml}^{-1}$ decolorized $72 \%$ of RBBR (200 $\mathrm{mg} \mathrm{l}^{-1}$ ) within $1 \mathrm{~h}$ [27]. Palmieri et al. [1] reported that Pleurotus ostreatus laccase at $1 \mathrm{U} \mathrm{ml}^{-1}$ decolorize $86 \%$ of RBBR (30 $\mathrm{mg} \mathrm{l}^{-1}$ ) within $1.7 \mathrm{~h}$. Soares et al. [28] reported that commercial laccase at $10 \mathrm{U} \mathrm{ml}^{-1}$ decolorize RBBR (20 $\mathrm{mg}^{-1}$ ) up to $72 \%$ within $1 \mathrm{~h}$. Sathishkumar et al. [11] applied RSM to optimized RBBR (52.90 $\mathrm{mg} \mathrm{l}^{-1}$ ) decolorization using Pleurotus florida laccase and achieved $82 \%$ of decolorization within $7.17 \mathrm{~min}$ by $1.87 \mathrm{U} \mathrm{ml}^{-1}$ of laccase in the presence of $0.85 \mathrm{mM} \mathrm{HBT}$. After statistical optimization, the rate of RBBR decolorization by $C$. caperata $\mathrm{DN}$ laccase at $1 \mathrm{U} \mathrm{ml}^{-1}$ is $542 \mathrm{mg} \mathrm{l}^{-1}\left(1000 \mathrm{mg} \mathrm{l}^{-1}\right)$ within $1 \mathrm{~h}$, which is better than those reported by other authors in previous studies (Table 5).

\section{Kinetic and Energetic Study of RBBR Dye Decolorization}

As shown in Fig. 1c, the linear relationship between the initial velocity and dye concentration proved that RBBR decolorization by enzyme is a first-order reaction. The $K_{\mathrm{m}}$ and $V_{\max }$ values of laccase determined through Lineweaver-Burk plot were $1.06 \mathrm{mM}$ and $0.226 \mathrm{mM} \mathrm{U}^{-1} \mathrm{~min}^{-1}$, respectively (Fig. 1d). The number of RBBR molecules turned over per laccase molecule $\left(K_{\text {cat }}\right.$ value) was $135.0 \mathrm{~S}^{-1}$. The second-order constant $\left(K_{\text {cat }} / K_{\mathrm{m}}\right)$ was $1.27 \times 10^{5} \mathrm{~S}^{-1} \mathrm{M}^{-1}$, indicating high catalytic power of enzyme. Sathishkumar et al. [11] reported that the $K_{\mathrm{m}}$ and $V_{\max }$ values of $P$. florida laccase for RBBR dye decolorization was $145.82 \mathrm{mg} \mathrm{l}^{-1}$ and $24.86 \mathrm{mg} \mathrm{l}^{-1} \mathrm{~min}^{-1}$, respectively, in the presence of laccase mediator HBT.

Arrhenius equation was used to study the effect of temperature on enzyme kinetics (Fig. 4b), and the calculated activation energy (Ea) for RBBR dye degradation was $10.87 \mathrm{~kJ} \mathrm{M}^{-1}$, which was similar to the activation energy $\left(14.25 \mathrm{~kJ} \mathrm{M}^{-1}\right)$ required for decolorization of acid blue 80 by laccase of Lentinus polychrous Lev. [32]. The Ea is the energy difference between the reactants and the activated complex, also known as transition state. The lower

Table 5 Application of different enzymes for decolorization of RBBR dye

\begin{tabular}{|c|c|c|c|c|c|c|c|}
\hline Enzyme & Source & $\begin{array}{l}\text { RBBR dye } \\
\text { (ppm) }\end{array}$ & $\begin{array}{l}\text { Laccase } \\
\left(\mathrm{U} \mathrm{ml}^{-1}\right)\end{array}$ & $\begin{array}{l}\text { Mediator } \\
(\mathrm{mM})\end{array}$ & Time & $\begin{array}{l}\text { Decolorization } \\
(\mathrm{mg})\end{array}$ & Reference \\
\hline Laccase & Pleurotus ostreatus & 31.30 & 1.0 & - & $1.7 \mathrm{~h}$ & 26.91 & {$[1]$} \\
\hline Laccase & Pleurotus florida & 52.90 & 1.87 & 0.85 & $7.17 \mathrm{~min}$ & 43.46 & {$[11]$} \\
\hline Laccase & Trametes pubescens & 133.0 & $0.5^{\mathrm{a}}$ & - & $42.0 \mathrm{~h}$ & 58.52 & {$[24]$} \\
\hline Laccase & $\begin{array}{c}\text { Myceliophthora } \\
\text { thermophila }\end{array}$ & 200.0 & $20.0^{\mathrm{a}}$ & 1.0 & $24.0 \mathrm{~h}$ & 62.0 & {$[25]$} \\
\hline Laccase & Ganoderma lucidum & 50.0 & 25.0 & 1.0 & $2.0 \mathrm{~h}$ & 46.0 & {$[26]$} \\
\hline Laccase & Trametes trogii & 100.0 & 0.2 & - & $1.0 \mathrm{~h}$ & 97.0 & {$[27]$} \\
\hline Laccase & Commercial laccase & 20.0 & 10.0 & - & $1.0 \mathrm{~h}$ & 14.4 & {$[28]$} \\
\hline $\begin{array}{l}\text { Soyabean } \\
\text { peroxidase }\end{array}$ & Soyabean seed hull & 40.0 & 70.4 & - & $13.0 \mathrm{~min}$ & 34.40 & [29] \\
\hline $\begin{array}{l}\text { Horseradish } \\
\text { peroxidise }\end{array}$ & Armoracia rusticana & 60.0 & 3.5 & - & $5.0 \mathrm{~min}$ & 57.60 & {$[30]$} \\
\hline $\begin{array}{l}\text { Bilirubin } \\
\text { Oxidase }\end{array}$ & $\begin{array}{l}\text { Myrotheclum } \\
\text { verrucaria }\end{array}$ & 100.0 & 10.0 & - & $4.0 \mathrm{~h}$ & 40.0 & [31] \\
\hline Laccase & $\begin{array}{l}\text { Coriolopsis caperata } \\
\text { DN }\end{array}$ & $\begin{array}{l}1000.0 \\
200.0\end{array}$ & $\begin{array}{l}1.0 \\
1.0\end{array}$ & $\begin{array}{l}- \\
-\end{array}$ & $\begin{array}{l}1.0 \mathrm{~h} \\
6.0 \mathrm{~min}\end{array}$ & $\begin{array}{l}542.0 \\
103.78\end{array}$ & $\begin{array}{r}\text { Present } \\
\text { work }\end{array}$ \\
\hline
\end{tabular}

${ }^{\mathrm{a}}$ Immobilized laccase enzyme used for decolorization of RBBR dye 
Fig. 4 Energetic studies of RBBR dye decolorization. a The velocities $\left(V_{0}\right)$ at temperature range $10-40{ }^{\circ} \mathrm{C}$ was plotted against initial dye concentration, b Arrhenius plot, c Van't Hoff plot, and $\mathbf{d}$ the Gibb's free energy $(\Delta G)$ changes plot

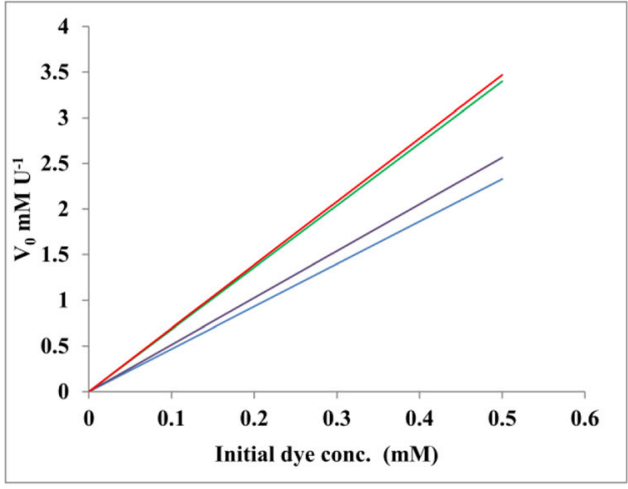

a

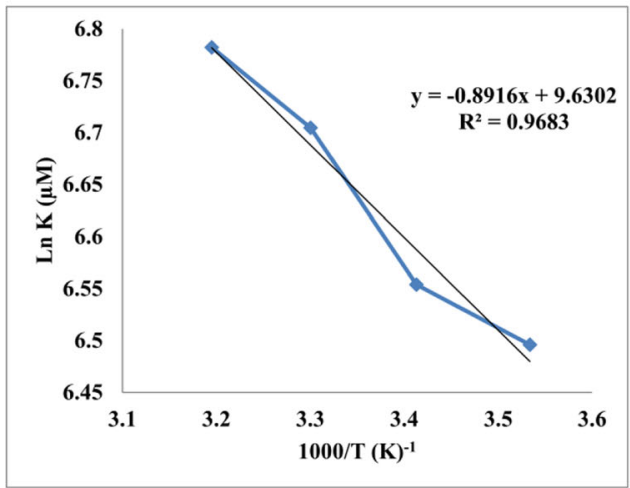

C

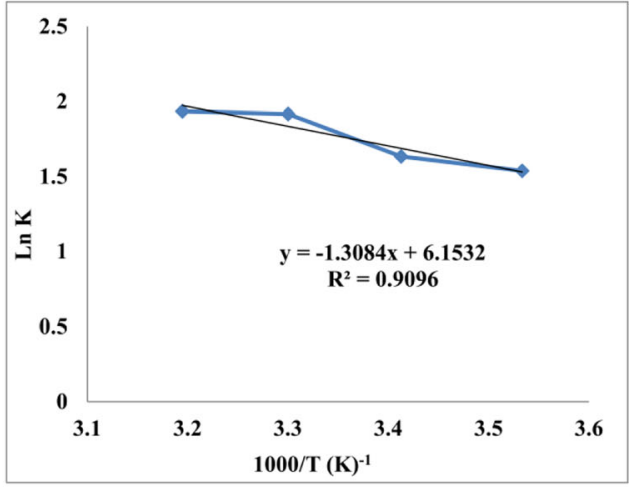

b

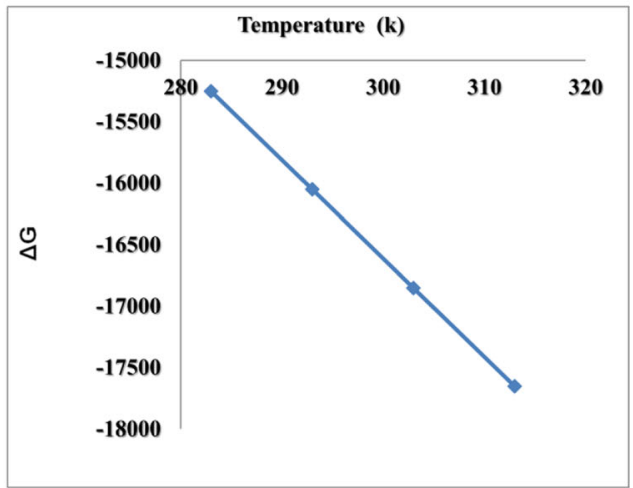

d activation energy (10.87 $\left.\mathrm{kJ} \mathrm{M}^{-1}\right)$ and $Q_{10}$ value (1.49) suggested that the reaction rate is faster and is less sensitive to a change in temperature. The calculated values for $\Delta H$ and $\Delta S$ were $7.408 \mathrm{~kJ} \mathrm{M}^{-1}$ and $80.06 \mathrm{~J} \mathrm{M}^{-1} \mathrm{~K}$, respectively. The lower enthalpy $(\Delta H)$ value showed that the formation of transition state or activated complex between enzyme and substrate was more efficient. The positive sign of $\Delta H$ and $\Delta S$ or the negative slope of Van't Hoff plot (Fig. $4 c)$ implies that the reaction is endothermic and spontaneous at higher temperature. The feasibility and extent of a chemical reaction is best determined by measuring change in $\Delta G$ for substrate catalysis. The negative value of $\Delta G$ suggested that the reaction is spontaneous (Fig. 4d).

\section{Analysis of Metabolites}

It is necessary to identify the metabolites produced from RBBR dye after laccase treatment in order to understand the mechanism of oxidative degradation of its chemically stable complex structure. Figure 2 shows the analysis result of RBBR dye degradation and metabolites formed after its treatment with laccase. The result of HPTLC analysis showed that the $\mathrm{Rf}$ value of RBBR dye is 0.58 at $592 \mathrm{~nm}$, while after laccase treatment, two new bands were obtained with $\mathrm{Rf}$ values 0.34 at $401 \mathrm{~nm}$ and 0.40 at $511 \mathrm{~nm}$ (Fig. 2 (a)). Similar results (Fig. $2(\mathrm{c} 1, \mathrm{c} 2)$ ) were observed in which a single major peak was obtained with control RBBR dye and two new peaks were obtained after laccase treatment. The results of FTIR analysis showed that 1634 peaks present in RBBR dye were absent in laccase-treated RBBR dye (Fig. 2 $(\mathrm{d} 1, \mathrm{~d} 2)$ ), indicating that the primary amine bond $(\mathrm{N}-\mathrm{H}$, 1650-1590) disappeared and two new products were produced. LC-MS analysis was carried out to investigate the degradation products of RBBR dye after laccase treatment. Figure 5 represents the chromatogram (a1) and mass spectral (b1) data of RBBR dye which showed a major peak with a retention time of $22.16 \mathrm{~min}$ and $\mathrm{m} / z$ value $627.60 \mathrm{Da}$. The chromatogram data of laccase-treated RBBR dye showed new peaks with retention time of $19.48 \mathrm{~min}$ and 21.06 (Fig. 5 (a2)). Mass spectral (Fig. 5 (b2)) data showed presence of intermediates having $\mathrm{m} / \mathrm{z}$ values 337.20 and $343.30 \mathrm{Da}$. The present study proposed that laccase oxidizes RBBR dye and produced two subproducts (sodium1amino-9,10-dioxo-9,10-dihydroanthracene-2-sulphonate and sodium 2-((3-aminophenyl) sulfonyl) ethyl sulfate) (Fig. 6), which is similar to the result reported by Osma et al. [24] and Hadibarata et al. [2].

\section{Toxicity Test}

\section{Phytotoxicity Test with P. mungo}

Effluent from dyeing industries may cause environmental and health hazard. Water after effluent treatment can be used for 


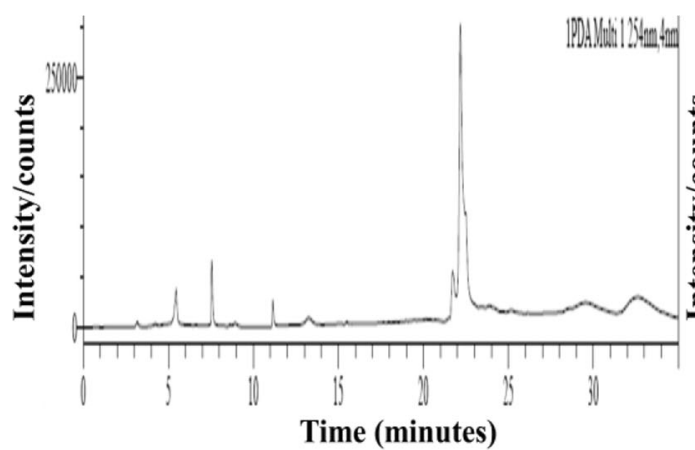

a1

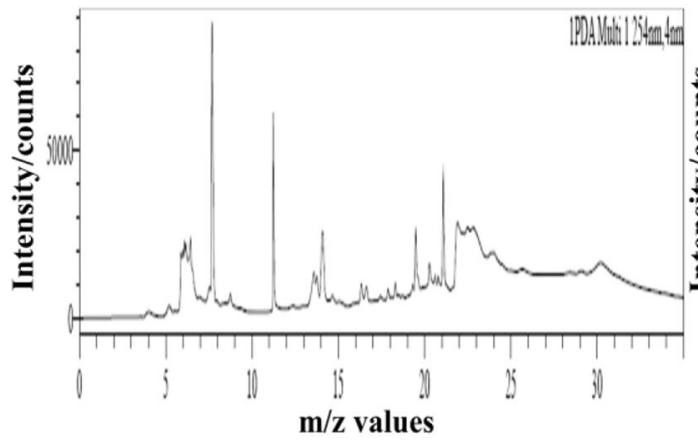

a2

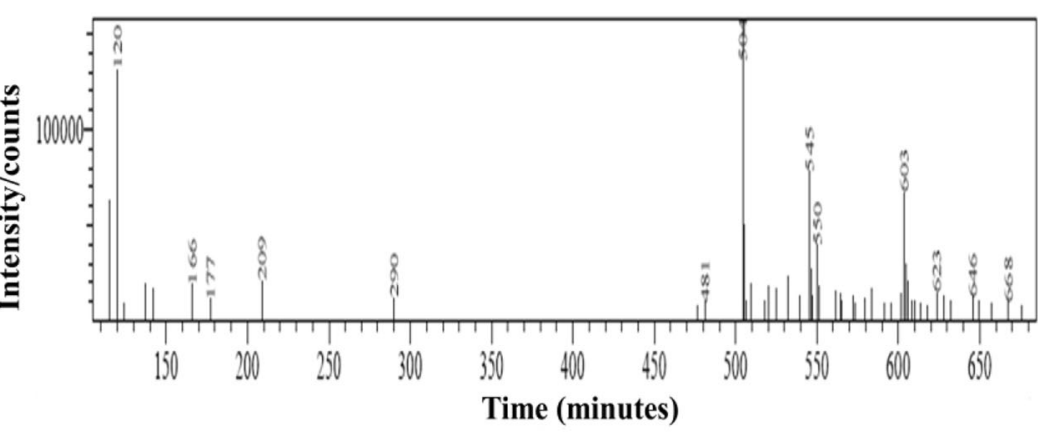

b1

Fig. 5 LC-MS analysis of $\operatorname{RBBR}$ dyes $(a 1, b 1)$ before and after laccase treatment $(a 2, b 2)$

agriculture, so it is necessary to assess the toxicity of dye and its degradation products. Zucconi et al. [33] used germination index (GI) to evaluate the phytotoxicity which combines relative seed germination and relative root elongation in presence of phytotoxic compound. P. mungo (dicot), normally cultivated in India was used to assess the toxicity of RBBR and metabolites formed after its decolorization. As shown in
Table 6, root elongation, percentage of seed germination, and the GI of seeds grown at $200 \mathrm{ppm}$ concentration of RBBR dye were found to be $12.5 \pm 8.4 \mathrm{~mm}, 75 \%$, and $40.5 \%$, respectively. Root elongation, percentage of seed germination, and the GI of seeds grown in the presence of laccase-treated RBBR dye were found to be $24.65 \pm 4.7$, $100 \%$, and $79.9 \%$, respectively. The $\mathrm{IC}_{50}$ value of $\mathrm{RBBR}$
Fig. 6 Product produced after laccase treatment to RBBR dye

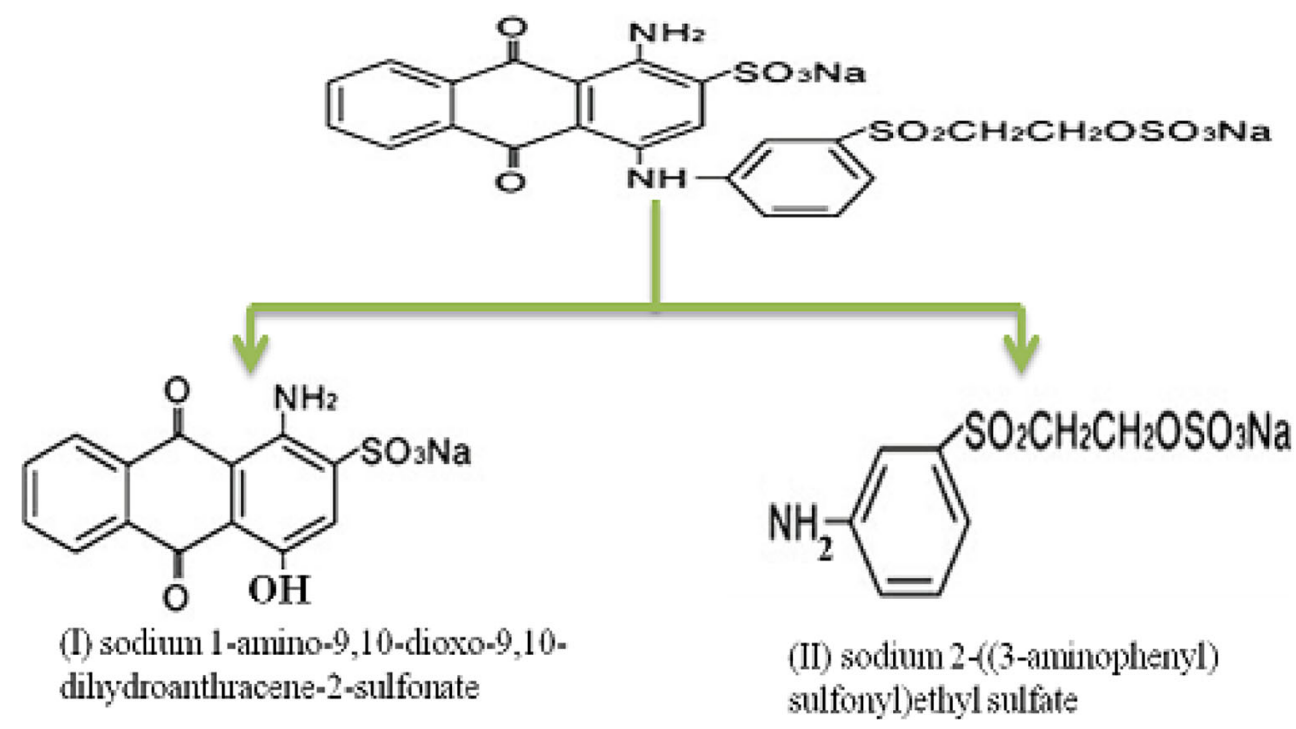


Table 6 Toxicity study of RBBR dye before and after laccase treatment using Phaseolus munga

\begin{tabular}{llllll}
\hline $\begin{array}{l}\text { Phytotoxicity } \\
\text { test }\end{array}$ & $\begin{array}{l}\text { RBBR } \\
\text { concentration } \\
\left(\mathrm{mg} \mathrm{l}^{-1}\right)\end{array}$ & $\begin{array}{l}\text { Seed } \\
\text { germination } \\
\text { number }\end{array}$ & $\begin{array}{l}\text { Root } \\
\text { elongation } \\
(\mathrm{mm})\end{array}$ & $\begin{array}{l}\text { Seed } \\
\text { germination } \\
(\%)\end{array}$ & $\begin{array}{l}\text { Germination } \\
\text { index }(\%)\end{array}$ \\
\hline Control & 00.0 & 20.0 & $30.85 \pm 6.6$ & 100.0 & 100 \\
RBBR dye & 200.0 & 15.0 & $12.5 \pm 8.4$ & 100.0 & 40.51 \\
& 100.0 & 17.0 & $18.75 \pm 8.8$ & 75.0 & 60.77 \\
& 50.0 & 19.0 & $21.55 \pm 6.9$ & 85.0 & 69.85 \\
Laccase-treated & 25.0 & 20.0 & $30.75 \pm 4.9$ & 95.0 & 99.67 \\
RBBR dye & 100.0 & 20.0 & $24.65 \pm 4.7$ & 100.0 & 79.90 \\
& 50.0 & 20.0 & $29.15 \pm 4.1$ & 100.0 & 94.48 \\
Laccase control & 00.0 & 20.0 & $31.00 \pm 3.3$ & 100.0 & 100.48 \\
\hline
\end{tabular}

The $t$ score and $p$ value for phytotoxicity (GI\%) were 5.87 and 0.0042 , respectively. The result is significant at $p \leq 0.01$

${ }^{\mathrm{a}}$ Mean \pm standard deviation

dye at 200 ppm concentration is 160 ppm (Fig. 7a). According to Zucconi et al. [33], less than 50\% GI value indicates high phytotoxicity, values between 50 and $80 \%$ mean moderate phytotoxicity, and more than $80 \%$ indicates no phytotoxicity. Thus, the toxicity of metabolites produced after the treatment of laccase from $C$. caperata DN to RBBR dye is much lower than that of RBBR dye, and similar result was reported by Osma et al. [24] and Sathishkumar et al. [11].

\section{Acute Toxicity Test with Cyclops}

The acute toxicity test was carried out using common water copepod Cyclops. After $24 \mathrm{~h}$ of incubation, the living Cyclops was counted and the calculated $50 \%$ lethal concentration $\left(\mathrm{LC}_{50}\right.$ ) was $40 \mathrm{mg} \mathrm{l}^{-1}$ (Fig. 7b). Verma [34] used Daphnia magna as an aquatic experimental animal and reported that the 48-h EC (50) value for the azo dyes, Remazol Parrot Green, and Remazol Golden Yellow was 46.84 and
$55.32 \mathrm{mg}^{-1}$, respectively. As shown in Table 7, the mortality percentage of Cyclops was related to the concentrations of RBBR dye and enzyme-treated dye as well as duration of exposure. The result showed that the acute toxicity of RBBR dye was significantly reduced after laccase treatment.

\section{Microtoxicity Test}

Many protocols have been used to determine the toxicity of chemical compounds based on the inhibition of growth of bacterial or animal cells. As shown in Table 8, the GI\% of RBBR dye at $100 \mathrm{ppm}$ for E. coli, E. aerogenes, M. luteus, S. aureus, and B. subtilis was found to be $35.06 \pm 3.06 \%$, $36.84 \pm 2.17 \%, 70 \pm 3.57 \%, 85 \pm 2.71 \%$, and $53.24 \pm 4.34 \%$, respectively, while the GI\% of laccasetreated RBBR dye was $2.59 \pm 1.05 \%, 5.26 \pm 1.87 \%$, $4.21 \pm 0.97 \%, 10 \pm 2.32 \%$, and $2.59 \pm 2.51 \%$, respectively. The result of the present study revealed that the toxicity of
Fig. 7 a Percentage of root growth inhibition of Phaseolus mungo and b percent mortality rate of Cyclops according to the concentration of RBBR dye before and after laccase treatment
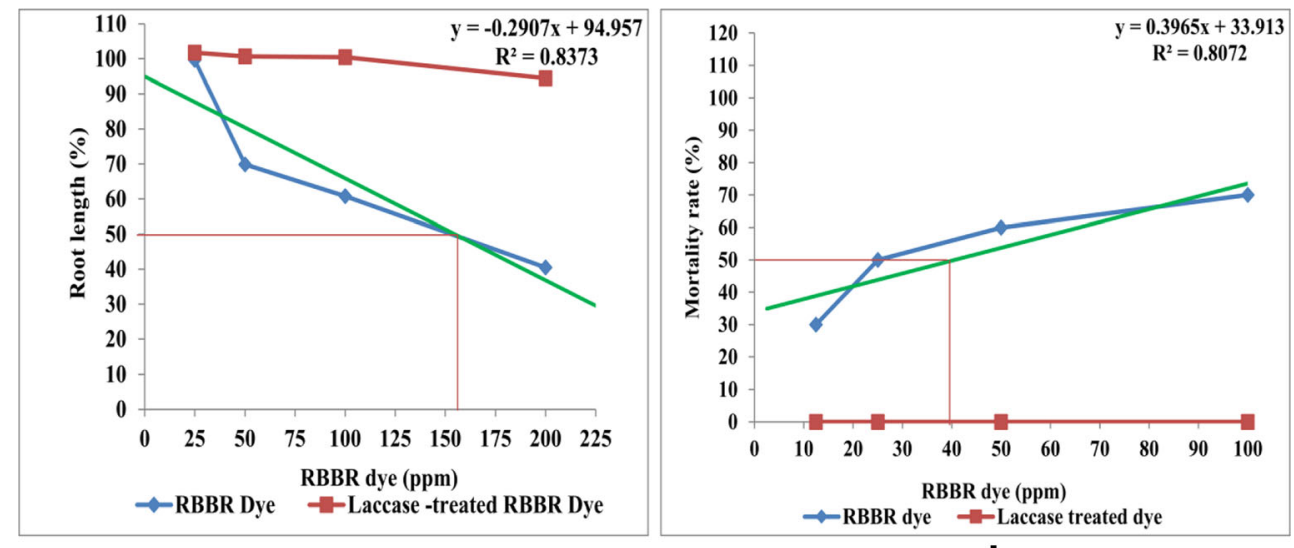

a 
Table 7 Toxicity study of RBBR dye before and after laccase treatment using Cyclops

\begin{tabular}{|c|c|c|c|c|c|c|}
\hline \multirow[t]{2}{*}{ Cytotoxicity test } & \multirow{2}{*}{$\begin{array}{l}\text { RBBR concentration } \\
\left(\mathrm{mg} \mathrm{l}^{-1}\right)\end{array}$} & \multirow{2}{*}{$\begin{array}{l}\text { Number of } \\
\text { Cyclops }\end{array}$} & \multicolumn{2}{|c|}{ Mortality rate ${ }^{\mathrm{a}}$} & \multicolumn{2}{|c|}{ Mortality rate $(\%)$} \\
\hline & & & $24 \mathrm{~h}$ & $48 \mathrm{~h}$ & $24 \mathrm{~h}$ & $48 \mathrm{~h}$ \\
\hline Control & 00.0 & 10.0 & 00.0 & 00.0 & 00.0 & 00.0 \\
\hline \multirow[t]{4}{*}{ RBBR dye } & 100.0 & 10.0 & $7.0 \pm 1.5$ & $10.0 \pm 0.0$ & 70.0 & 100.0 \\
\hline & 50.0 & 10.0 & $6.0 \pm 0.5$ & $10.0 \pm 0.0$ & 60.0 & 100.0 \\
\hline & 25.0 & 10.0 & $5.0 \pm 1.0$ & $10.0 \pm 0.5$ & 50.0 & 100.0 \\
\hline & 12.5 & 10.0 & $3.0 \pm 1.0$ & $9.0 \pm 1.0$ & 30.0 & 90.0 \\
\hline \multirow{4}{*}{$\begin{array}{l}\text { Laccase-treated } \\
\text { RBBR dye }\end{array}$} & 100.0 & 10.0 & 00.0 & $2.0 \pm 0.5$ & 00.0 & 20.0 \\
\hline & 50.0 & 10.0 & 00.0 & 00.0 & 00.0 & 00.0 \\
\hline & 25.0 & 10.0 & 00.0 & 00.0 & 00.0 & 00.0 \\
\hline & 12.5 & 10.0 & 00.0 & 00.0 & 00.0 & 00.0 \\
\hline Laccase control & 00.0 & 10.0 & 00.0 & 00.0 & 00.0 & 00.0 \\
\hline
\end{tabular}

The $t$ score and $p$ value for cytotoxicity $(24 \mathrm{~h})$ were 9.39 and $3.2 \mathrm{E}-05$, respectively. The result is significant at $p \leq 0.01$

${ }^{\mathrm{a}}$ Mean \pm standard deviation
RBBR dye significantly reduces after laccase treatment, and the metabolites produced are less toxic. Palmieri et al. [1] used laccase of Pleurotus ostreaatus to decolorize RBBR dye and reported 95\% viability of Bacillus cereus after laccase treatment of RBBR dye, which is similar to our results. Increased toxicity of enzyme-treated RBBR dye was reported by Champagne and Ramsay [35] who used laccase and Maria et al. [29] using soyabean peroxidase.

\section{Conclusions}

This is the first report which statistically evaluates the potential use of laccase enzyme from C. caperata $\mathrm{DN}$ to decolorize anthraquinone dye RBBR which represents an important class of toxic and recalcitrant organopollutants. The kinetic study follows Michaelis-Menten model and thermodynamic parameters of the laccase enzyme suggests that this enzyme has great potential to be used commercially for large-scale treatment of industrial effluents. The analysis of laccase-treated RBBR dye solution showed that laccase oxidizes RBBR dye and degrades it into two end products. The toxicity tests showed that after laccase treatment, the toxicity of RBBR dye was significantly reduced. Laccase enzyme $\left(1 \mathrm{U} \mathrm{ml}^{-1}\right)$ from $C$. caperata DN efficiently decolorize and detoxify $51.89 \%$ of $200 \mathrm{ppm}$ RBBR dye within 6.0 min and $54.2 \%$ of 1000 ppm RBBR dye within $60.0 \mathrm{~min}$ without mediator, suggesting higher catalytic efficiency of laccase as compared with the ones reported. Thus, present study evaluates laccase produced by C. caperata $\mathrm{DN}$ as green catalyst to replace conventional oxidation processes generally applied for bioremediation of environmental pollutants.

Table 8 Toxicity study of RBBR dye before and after laccase treatment using microorganisms

\begin{tabular}{|c|c|c|c|c|c|}
\hline \multirow[t]{3}{*}{ Microtoxicity test } & \multicolumn{5}{|c|}{ Percentage inhibition of bacterial strain ${ }^{a}$} \\
\hline & \multicolumn{5}{|l|}{ Test organisms } \\
\hline & Escherichia coli & Enterobacter aerogenes & Micrococcus luteus & Staphylococcus aureus & Bacillus subtilis \\
\hline Control & 00.0 & 00.0 & 00.0 & 00.0 & 00.0 \\
\hline RBBR dye $\left(100 \mathrm{mg}^{-1}\right)$ & $35.06 \pm 3.06$ & $36.84 \pm 2.17$ & $70.00 \pm 3.57$ & $85.0 \pm 2.71$ & $53.24 \pm 4.34$ \\
\hline Laccase-treated RBBR dye & $2.59 \pm 1.05$ & $5.26 \pm 1.87$ & $4.21 \pm 0.97$ & $10.0 \pm 2.32$ & $2.59 \pm 2.51$ \\
\hline
\end{tabular}

The $t$ score and $p$ value for microtoxicity were 5.87 and 0.0042 , respectively. The result is significant at $p \leq 0.01$

${ }^{\mathrm{a}}$ Mean \pm standard deviation 
Acknowledgments Ajit M. Patel received financial support from University Grant Commission, Government of India, New Delhi, as minor research project. (UGC approval Letter No. and Date: File No. 47508/12 (WRO) 7th March 2013).

\section{Compliance with Ethical Standards}

Conflict of Interests The authors declare that they have no conflict of interest.

\section{References}

1. Palmieri G, Cennamo G, Sannia G (2005) Remazol Brilliant Blue R decolourisation by the fungus Pleurotus ostreatus and its oxidative enzymatic system. Enzym Microb Technol 3:17-24

2. Hadibarata T, Yusoff ARM, Kristanti RA (2011) Decolorization and metabolism of anthraquinone-type dye by laccase of whiterot fungi Polyporus sp. S113. Water Air Soil Pollut 223:933-941

3. Ghaly, A.E., Ananthashankar, R., Alhattab, M., \& Ramakrishnan, V.V. (2014). Production, characterization and treatment of textile effluents: a critical review. J Chem Eng Process Technol, 5. Doi: 10.4172/2157-7048.1000182

4. Buddolla V, Bandi R, Avilala J, Arthala PK, Golla N (2014) Fungal laccases and their applications in bioremediation. Enzyme Res 2014:1-22

5. Wang XJ, Gu XY, Lin DX (2007) Treatment of acid rose dye containing wastewater by ozonizing-biological aerated filter. Dyes Pigments 74:736-740

6. Luciana P, Madalena A (2012) Dyes - environmental impact and remediation. In: Malik A, Grohmann E (eds) Environmental protection strategies for sustainable development. Springer Science+ Business Media, pp 111-162

7. Arora DS, Sharma RK (2010) Ligninolytic fungal laccases and their biotechnological applications. Appl Biochem Biotechnol 160: 1760-1788

8. Mohammadian FM, Mesdaghinia AR, Naddafi K, Nasseri S, Yunesian M, Assadi MM et al (2010) Optimization of reactive blue 19 decolorization by Ganoderma sp. using response surface methodology. Iran J Environ Health Sci Eng 7:35-42

9. Sharma YC, Singh BU (2009) Fast removal of malachite green by adsorption on rice husk activated carbon. Open Environ Pollution Toxicol J 1:74-78

10. Upadhyay P, Shrivastava R, Agrwal PK (2016) Bioprospecting and biotechnological applications of fungal laccase. 3 Biotech 6:15. doi: 10.1007/s13205-015-0316-3

11. Sathishkumar P, Balan K, Palvannan T, Kamala-Kannan S, Oh BT, Rodríguez-Couto S (2013) Efficiency of Pleurotus florida laccase on decolorization and detoxification of the reactive dye Remazol Brilliant Blue R (RBBR) under optimized conditions. Clean-Soil Air Water 41:665-672

12. Niku-Paavola ML, Karhunen E, Salola P, Raunio V (1988) Ligninolytic enzymes of the white-rot fungus Phlebia radiate. Biochem J 254:877-884

13. Prajapati VS, Trivedi UB, Patel KC (2014) Kinetic and thermodynamic characterization of glucoamylase from Colletotrichum $\mathrm{sp}$. KCP1. Indian J Microbiol 54:87-93

14. Xin F, Geng A (2011) Utilization of horticultural waste for laccase production by Trametes versicolor under solid-state fermentation. Appl Biochem Biotechnol 163:235-246
15. Maniknandan M, Pasic L, Kannan V (2009) Optimization of growth medium for obtaining hign-cell density cultures of halophilic archaea (family Halobacteriaceae) by response surface methodology. Bioresour Technol 100:3107-3112

16. Annuar MSM, Adnan S, Vikineswary S, Chisti Y (2009) Kinetics and energetics of azo dye decolorization by Pycnoporus sanguineus. Water Air Soil Pollut 202:179-188

17. Marus EM, Elphick JR, Bailey HC (2015) A new toxicity test using the freshwater copepod Cyclops vernalis. Bull Environ Contam Toxicol 95:357-362

18. Erkurt EA, Unyayar A, Kumbur H (2007) Decolorization of synthetic dyes by white rot fungi, involving laccase enzyme in the process. Process Biochem 42:1429-1435

19. Faraco V, Pezzella C, Miele A, Giardina P, Sannia G (2009) Bioremediation of colored industrial wastewaters by the white-rot fungi Phanerochaete chrysosporium and Pleurotus ostreatus and their enzymes. Biodegradation 20:209-220

20. VinothKumar V, Sathyaselvabala V, Premkumar MP, Vidyadevi T, Sivanesan S (2012) Biochemical characterization of three phase partitioned laccase and its application in decolorization and degradation of synthetic dyes. J Mol Catal B Enzym 74:63-72

21. Mirzadeh SS, Khezri SM, Rezaei S, Forootanfar H, Mahvi AH, Faramarzi MA (2014) Decolorization of two synthetic dyes using the purified laccase of Paraconiothyrium variabile immobilized on porous silica beads. J Environ Health Sci Eng. doi:10.1186/2052336X-12-6

22. Baldrian P (2006) Fungal laccases-occurrence and properties. FEMS Microbiol Rev 30(215-2):42

23. Ashrafi SD, Rezaei S, Forootanfar H, Mahvi AH, Faramarzi MA (2013) The enzymatic decolorization and detoxification of synthetic dyes by the laccase from a soil-isolated ascomycete, Paraconiothyrium variabile. Int Biodeter Biodegr 85:173-181

24. Osma JF, Toca-Herrera JL, Rodríguez-Couto S (2010) Transformation pathway of Remazol Brilliant Blue R by immobilised laccase. Bioresour Technol 101:8509-8514

25. Kunamneni A, Ghazi I, Camarero S, Ballesteros A, Plou FJ, Alcalde M (2008) Decolorization of synthetic dyes by laccase immobilized on epoxy-activated carriers. Process Biochem 43: 169-178

26. Murugesan K, Nam IH, Kim YM, Chang YS (2007) Decolorization of reactive dyes by a thermostable laccase produced by Ganoderma lucidum in solid state culture. Enzym Microb Technol 40:16621672

27. Mechichi T, Mhiri N, Sayadi S (2006) Remazol Brilliant Blue R decolorization by the laccase from Trametes trogii. Chemosphere 64:998-1005

28. Soares GMB, Pessoa-de Amorim MT, Costa-Ferreira M (2001) Use of laccase together with redox mediators to decolorize Remazol Brilliant Blue R. J Biotechnol 89:123-129

29. Silva MC, Torres JA, Vasconcelos de Sa LR, Chagas PMB, Ferreira-Leitão VS, Corrêa AD (2013) The use of soybean peroxidase in the decolourization of Remazol Brilliant Blue R and toxicological evaluation of its degradation products. J Mol Catal B Enzym 89:122-129

30. Reis da Silva M, Vasconcelos de Sa LR, Russo C, Scio E, FerreiraLeitão VS (2010) The use of HRP in decolorization of reactive dyes and toxicological evaluation of their products. Enzyme Res. doi:10. 4061/2010/703824

31. Liu Y, Huang J, Zhang X (2009) Decolorization and biodegradation of Remazol Brilliant Blue R by bilirubin oxidase. J Biosci Bioeng 108:496-500 
32. Ratanapongleka K, Phetsom J (2014) Decolorization of synthetic dyes by crude laccase from Lentinus polychrous Lev. IJCEA 5:2630

33. Zucconi F, Monaco A, Forte M, Bertoldi MD (1985) Phytotoxins during the stabilization of organic matter, in composting of agricultural and other wastes. In: Gasser JKR (ed) Commission European communities. Elsevier, London, pp 73-86
34. Verma Y (2008) Acute toxicity assessment of textile dyes and textile and dye industrial effluents using Daphnia magna bioassay. Toxicol Ind Health 24:491-500

35. Champagne PP, Ramsay JA (2010) Dye decolorization and detoxification by laccase immobilized on porous glass beads. Bioresour Technol 101:2230-2235 